Swiss Federal Research Station for Animal Production'. Posicux, Switzerland, and Institute of Animal Scionces, Ciroup of Animal Nutrition? ${ }^{2}$ Swiss Federal institute of Technology (ETH) Zurich, Switzerland

\author{
ALAIN CHAMBAZ', ISABELLE MOREL', MARTIN R, L, SCHEEDER ${ }^{2}$, \\ MICHAEL KREUZER ${ }^{2}$ and PIERRE-ALAIN DUFEY'
}

\title{
Characteristics of steers of six beef breeds fattened from eight months of age and slaughtered at a target level of intramuscular fat
}

\section{Growth performance and carcass quality}

\author{
Dedicated to Prof. Dr. Dr. h. c. mult. Horst Kräußlich on the occasion of his \\ $75^{\text {th }}$ birthday
}

\begin{abstract}
Summary
Growth performance and carcass quality of 132 steers originating from six beef breeds, Angus (AN), Simmental (SI), Charolais $(\mathrm{CH})$, Limousin (LI), Blonde d'Aquitaine (BL), and Piedmontese (PI), fattened under the same conditions on the same diet, were compared at a target level of $3.5 \%$ intramuscular fat (IMF) in the $M$. longissimus dorsi, This target level was set on basis of the results of a preliminary study investigating, with 784 persons, the visual preference of marbling using photographs. The total mix ration, provided at ad libinum access, consisted of maize silage, grass silage and concentrate $(52 \%, 26 \%$ and $22 \%$ of DM, resp.). Series I was performed in a tie-stall barn while a loose-housing system with straw bedding was used in series 2 . The animals were assigned to slaughter either when the Iarget IMF content was reached according to the estimation with a real-time ultrasound system applied in the live animals or when 15 months of fattening had passed. AN, SI, CH and $\mathrm{LI}$ reached $3.5 \% \mathrm{IMF}$ on average at final weights of $501 \pm 43,628 \pm 60,693 \pm 117$ and $668 \pm 65 \mathrm{~kg}$, respectively. BL and PI did not reach this target, although the average fattening period was about three times longer for BL and PI than for AN and the final weights were $758 \pm 93$ and $647 \pm 64 \mathrm{~kg}$, respectively. Under the conditions of this experimental approach, daily gains were highest in $\mathrm{AN}$, followed by $\mathrm{CH}, \mathrm{SI}, \mathrm{LI}$ and $\mathrm{BL}$ and lowest in PI. The daily feed intake was significantly lower for $\mathrm{PI}$ than for $\mathrm{CH}, \mathrm{SI}$ and $\mathrm{AN}$. The AN expressed the best feed conversion efficiency in terms of DM expenditure per $\mathrm{kg}$ gain over the complete fattening period while this efficiency was lowest in the PI group followed by BL. Among the four breeds, which reached the target IMF content, LI steers showed the greatest proportion of premium cuts and the highest lean to fat and lean to bone ratio in the sirloin, followed, in descending order, by $\mathrm{CH}, \mathrm{SI}$ and $\mathrm{AN}$. However all four groups were graded around 4 in fatness score (high to very high). The present results revealed for all breeds the difficulty to reach the desired extent of marbling and at the same time favourable carcass conformation, carcass size (except AN) and fat cover which meet market demands.
\end{abstract}

Key Words: fattening, steers, breed, growth, carcass quality, intramuscular fat, marbling

\section{Zusammenfassung}

Titel der Arbeit: Mast von Ochsen sechs verschiedener Fleischrinderrassen ab einem Alter von acht Monaten bis zum Erreichen eines Zielwerts im intramuskulären Fettgehait. 1. Mitt.: Wachstumsleistung und Schlacht-körperquatität

Die Mast- und Schlachtleistung von 132 Ochsen sechs verschiedener Mastrassen, nümlich Angus (AN), Simmental (SI), Charolais (CH), Limousin (LI), Blonde d'Aquitaine (BL) und Piemonteser (PI), wurde erfasst. Die Mast erfolgte für alle Tiere unter gleichen Bedingungen und mit derselben Futterration, wobei derselbe Zielwert von 3,5\% intramuskularem Fett (IMF) im M. longissimus dorsi angestrebt wurde. Dieser Zielwert wurde auf Basis der Ergebnisse einer Vorstudie festgelegt, in der 784 Personen ihre visuelle Praferenz der Marmorierung anhand von Fotographien festlegten. Die Total-Mix-Ration, welche ad libitum vorgelegt wurde, bestand zu $52 \%$ und $26 \%$ aus Mais- und Grassilage sowie zu $22 \%$ aus Kraftutter (Angaben in T). Der erste Mastdurchgang wurde in einem Anbindestall durchgefuhrt, der zweite in einem Laufstall mit stroheingestreuten Liegeboxen. Die 
Tiere wurden geschlachtet, wenn sie nach den Ergebnissen einer Schătzung am lebenden Tier mittels EchtzeitUitraschall entweder den Zielwert im IMF-Gehalt erreicht hatten oder 15 Monate Mast vergangen waren. AN, SI, CH and LI erreichten 3.5\% IMF im Mittel mit Endmassen von $501 \pm 43,628 \pm 60,693 \pm 117$ und $668 \pm 65$ $\mathrm{Kg}$. Die BL- and PI-Ochsen erreichten den Zielwert uberhaupt nicht, obwohl die Mastperiode für sie ungefahr dreimal solang war als fur die $\mathrm{AN}$ und ihre Endmassen im Mittel bei $758 \pm 93$ und $647 \pm 64 \mathrm{~kg}$ lagen. Unter den Bedingungen des vorliegenden experimentellen Ansatzes wiesen die AN, gefolgt von $\mathrm{CH}, \mathrm{SI}, \mathrm{LI}$ und $\mathrm{BL}$, die höchsten Tageszunahmen auf und waren bei den PI am niedrigsten. Der mittlere tägliche Futterverzehr war fur PI signifikant niedriger als fur CH, SI und AN. Die AN-Ochsen erreichten uber die gesamte Mastperiode gesehen die beste Futterverwertung, ausgedrückt als $\mathrm{kg}$ T-Aufnahme je kg Zuwachs, wăhrend die Verwertung der PI am geringsien war, gefolgt von den BL-Ochsen. Unter den vier Rassen, welche den Zielwert im IMF-Gehalt erreichten, wiesen die LI-Ochsen den høchsten Anteil wertvoller Teilstucke und das weiteste Verhältnis von Magerfleisch zu Fett bzw. Magerfleisch zu Knochen im Roastbeef auf. Diese Merkmale fielen yon CH uber SI und AN zunehmend ungünstiger aus. Alle vier Gruppen wurden jedoch in der Verfettung im Bereich der Stufe 4 (fett bis schr fett) klassiert. Die vorliegenden Ergebnisse belegten für alle Rassen, dass es schwierig war, das gewünschte Ausmaß an Marmorierung und gleíchzeílig eine Konformation, Größe (ausser AN) und Fettabdeckung der Schlachtkörper zu erreichen, die den Marktbedürfnissen entspricht.

Schlüsselwörter: Mast, Ochsen, Rasse, Wachstum, Schlachıkörperqualität, intramuskuläres Fett, Marmorierung

1. Introduction

Over the last decades, consumers increasingly demand and purchase beef produced under conditions as natural as possible (BADERTSCHER FAWAZ et al., 1998). This includes suckler cow systems, forage-based diets and the ban of artificial growth enhancers (HARRINGTON, 1994) and encouraged the development of a multitude of beef label programs (DUFEY and CHAMBAZ, 1999). Generally, one aim of these label programs is to achieve a clear differentiation from the conventional production as for instance by prescribing a certain type of diet, fattening steers instead of bulls and/or the use of beef breeds or crossbreds, the latter particularly in countries where beef production is largely a by-product of dairy husbandry (GEAY and MICOL, 1988) like Germany (AUGUSTINI et al., 1990) and Switzerland (DUFEY and CHAMBAZ, 1999). Carcasses and meat of improved quality are expected from these labels when compared with conventionally produced beef, particularly in sensory respect (BUTTERY et al., 1997). One major visual component affecting purchase decision of the consumers is marbling, which describes the visible proportion and distribution of intramuscular fat (IMF) as determined in the M. longissimus dorsi (M.l.d.) (SAVELL and CROSS, 1988). Marbling is often monitored in breed comparisons but was rarely used as the decisive slaughter criterion. Typically, animals in such studies were slaughtered at the same chronological age (DIKEMAN and CROUSE, 1975; RILEY et al., 1986; OLDIGS et al., 1989), physiological age (GEAY and ROBELIN, 1979), or weight (DUBESKI et al., 1997). Few investigations applied the same fatness score (SCHLÄPFER, 1986; KAUFMANN and CHAVAZ, 1989) as slaughter criterion or used the same percentage of carcass fat, applying a posteriori selection (GEAY and MALTERRE, 1973). To our knowledge, only in one study (SMITH et al., 1976) growth and feed efficiency of different beef crosses were compared at a distinct IMF content $(5 \%)$, which was performed by statistical adjustment of means and the application of a regression for days on feed.

The objective of the present experiment was to compare growth performance, carcass traits and meat quality of steers at the same target IMF content of $3.5 \%$ in M.l.d. The steers originated from six beef breeds and were fattened under the same conditions on 
an identical forage-based diet for all animals. This first communication focuses on results concerning growth and slaughter performance. Meat quality issues are described in a subsequent communication (CHAMBAZ et al., 2001).

2.

2.1 Animals and experimental design

A total of 132 steers originating from six beef breeds, Angus (AN), Simmental (SI; original without Red Holstein blood), Charolais ( $\mathrm{CH}$; line 'maternal quality'), Limousin (LI), Blonde d'Aquitaine (BL), and Piedmontese (PI), were used in this study. AN and SI were obtained from Swiss farms, CH, BL and LI were imported from France and PI from Italy. All animals were purebred, except AN (75\% AN blood on average) which had been derived from grading up native Swiss dairy breeds mainly by the use of American AN bulls. Two subsequent fattening series were carried out, each including 11 steers per breed. Series 1 was performed in a tie-stall barn (space allowance per animal: $0.95 \times 1.86 \mathrm{~m}$ ), while a loose-housing system with straw bedding $\left(10 \mathrm{~m}^{2}\right.$ per animal including an outside area) was used in series 2 due to the intermediately performed transformation of the barns. All imported animals had to pass a 3-week period of quarantine in the country of origin as well as in Switzerland. During the quarantine in Switzerland the animals were already adapted to the experimental diet. All steers were purchased from suckler herds at the same time and entered the trial at a similar average age of $238 \pm 22,236 \pm 25,235 \pm 29,249 \pm 19$, $230 \pm 21$ and $240 \pm 13 \mathrm{~d}$ (means \pm SD) for AN, SI, CH, LI, BL and PI (PI, only series $2)$, respectively. In series 1 , the PI had to pass a prolonged quarantine in Italy and started the experiment at an average age of $281 \pm 16 \mathrm{~d}$. All steers were weighed at the start and at the end of fattening (directly before transport to slaughter) as well as periodically every two weeks during fattening.

\section{$2.2 \quad$ Diet}

A total mix ration consisting of maize silage, grass silage (early-cut grass-clover mixture) and concentrate was provided. Table 1 gives the ingredient and nutrient composition of this diet and its components. The concentrate consisted per $\mathrm{kg}$ of $400 \mathrm{~g}$ barley, $240 \mathrm{~g}$ soybean meal, $200 \mathrm{~g}$ triticale, $100 \mathrm{~g}$ wheat and $60 \mathrm{~g}$ mineral-vitamin premix. Maize silage and grass silage were offered in a ratio of $2: 1$ in terms of dry matter based on 2-weekly determinations owing to the fact that growing cattle have high requirements for energy relative to protein. In addition, samples from all diet components were taken every two weeks for nutrient compositional analysis. There were only small differences between the two series in the nutrient content of forages and concentrate, while certain variations were found within series particularly when using new batches of grass silage.

Concentrate proportion was calculated in a way that the complete ration, being provided ad libitum, generally covered the requirements for both net energy for growth (NEV) and absorbable protein at the duodenum (APD) at the start of fattening. These requirements were calculated on the basis of the Swiss recommendations developed for dairy crossbred steers expecting average daily gains of $1.2 \mathrm{~kg} / \mathrm{d}$ (RAP, 1999). The 
mineral-vitamin premix was designed to supplement deficiencies and imbalances of the ration. Breed specific differences in nutrient requirements were deliberately not accounted for in this study in order to exclude direct diet effects. The composition of the ration was not changed during fattening. This procedure may have resulted in a certain excess of protein as the fattening period proceeded but ensured that deficiencies were avoided. The increasing demand for energy with growing live weight was covered by the associated increase of the intake capacity of the steers at a constant medium energy density of the complete ration. Feed intake of each steer was recorded daily in both series. In series 2 this was accomplished by the use of electronically controlled doors (Insentec, NL-Marknesse).

Table 1

Composition and nutrient contents of the experimental diet (means \pm SD)' (Zusammensetzung und Nährstoffgehalte der Versuchsration, Mittelwert \pm SD)



\section{$2.3 \quad$ Endpoint of fattening}

The aim of this investigation was to slaughter all animals when they reached a similar IMF content. The target IMF level was determined in a preliminary study investigating the visual preference of marbling. In that study, 784 persons ( $46 \%$ female, $54 \%$ male; $11.3 \%<21,29.3 \%$ between 21 and $40,45.1 \%$ between 41 and $60,14.3 \%>60$ years of age) had to select the most preferred out of six photographs of M.I.d. cuts taken between the $9^{\text {th }}$ and $10^{\text {th }}$ rib, which represented six classes of IMF content covering the range from 1 to $6 \%$. The photographs showed only the central part of the slice to exclude any influence of the shape of the M.I.d. and were presented without noticeable colour difference to avoid potential bias due to colour. The most frequently selected marbling classes were either the ones with $3 \%$ and $4 \%$ IMF with $30 \%$ and $17 \%$, respectively, or the class without any marbling ( $27 \%$ of the responses). The 2,5 and 6 $\%$ IMF classes were only chosen by 14,6 and $5 \%$ of the participants. A range of 3 to $4 \%$ IMF is also often quoted in other studies as to be the minimum level necessary for the subjective perception as 'good beef quality' (CAMPION and CROUSE, 1975; GOUTEFONGEA and VALIN, 1978; SAVELL and CROSS, 1988). For these reasons a content of $3.5 \%$ IMF in M.I.d. was chosen as the target value. The IMF content was estimated with a real-time ultrasound system in the live animals. Images were captured 
with a Pie Medical scanner 200 SLC (NL-Maastricht) equipped with a $3.5 \mathrm{MHz}, 18$ cm transducer (Model ASP-18) and a computer program, which provides the opportunity for chute-side evaluation of IMF (Classic ultrasound equipment, Tequesta, USA-Florida). This program was developed for beef animals up to 24 months of age (GRESHAM, 1996). The hair was clipped and linseed oil was applied to the skin before scanning to ensure sufficient acoustical contact between probe and skin surface. The probe was centred directly above the $12^{\text {th }}$ and $13^{\text {th }}$ rib and placed lateral from the backbone of the animal at a point situated approximately in the middle of the M.I.d. Applying this technique finally yielded chemically analysed average IMF contents of $3.35 \pm 1.12,3.47 \pm 0.93,3.49 \pm 1.11,3.48 \pm 1.08,2.34 \pm 0.64$ and $2.40 \pm 0.63$ for AN, SI, CH, LI, BL and PI, respectively. This illustrates that the target value was reached on average only in four breeds whereas this was impossible for BL and PI. However, BL and PI were kept in the comparison in order to give an impression of their performance under the specific conditions of this experimental approach. For further details on IMF content see CHAMBAZ et al. (2001).

\subsection{Data and sample collection at slaughter}

The animals were slaughtered without subsequent electrical stimulation of the carcasses at a commercial slaughter plant. Hot carcass weights were determined at about $1 \mathrm{~h}$ post mortem. Carcass grading was performed by experienced official staff according to the Swiss beef classification grid (PROVIANDE, 2001), which is widely equivalent to the EUROP grading system. Subcutaneous fat thickness was measured 2 days post mortem between the $12^{\text {th }}$ and $13^{\text {th }}$ rib at $3 / 4$ of the distance of the lateral length of the M.l.d. from the backbone with an electronic calliper square. Carcass length was measured from the $1^{\text {st }}$ rib to the head of the Symphysis ossium pubis and the leg length from the head of the Symphysis ossium pubis up to the Os malleolare. After chilling for $48 \mathrm{~h}$, the left side of the carcass was divided into fore- and hindquarter between the $9^{\text {th }}$ and $10^{\text {th }}$ rib. The flank was cut along the distal edge of the M. iliocostalis lumborum through the ribs until joining the cut along the $9^{\text {th }} / 10^{\text {th }}$ ribs. This procedure divided the carcass into pistola and forequarter with adhered flank. The pistola was then separated $5 \mathrm{~cm}$ cranial of the head of the Symphysis ossium pubis into leg and sirloin together with the rump. The separation between the sirloin and the rump was done behind the $6^{\text {th }}$ lumbar vertebra. The sirloin was furthermore dissected into striploin (i.e., M.I.d.), tenderloin (i.e., M. psoas major), bone and fat tissue. The proportion of the so-called $1^{\text {st }}$ category cuts comprised the trimmed striploin, tenderloin and rump (M. glutaeus medius). The dressing procedure followed guidelines of ABZ (1997).

\section{$2.5 \quad$ Statistical analysis}

Data were statistically analysed with the NCSS program (version 1997, Hintze, Kaysville, Utah, USA). In a first evaluation, data of both series were included in order to be able to compare overall series differences, using a two-way ANOVA with breeds and series as fixed effects and breed $x$ series interactions. Because interactions between breed and series occurred in most growth variables, the data were finally analysed separately for each series with one-way ANOVA considering breed as fixed 
effect in the model. The Tukey test was used for multiple comparison among means considering $\mathrm{p}<0.05$ as significant.

3.

Results

3.1

Growth performance

The steers of the different breeds were of a similar age at the start of the experiment, except for the PI in series 1 which were older by $40 \mathrm{~d}$ at the start as explained (2.1), but there were already certain initial differences in live weight (Table 2). Weight was highest in the $\mathrm{CH}$ steers (significant in series 2) and lowest in the PI steers (series 2) at the start of fattening. At slaughter, when the target IMF content was reached by AN, SI, CH and LI steers, AN steers were significantly lightest in both series. All other

Table 2

Growth characteristics of the steers originating from different beef breeds ( $n=11$ per series) (Wachstumsmerkmale der Ochsen von verschiedenen Mastrassen; $n=11$ je Versuchsdurchgang)

\begin{tabular}{|c|c|c|c|c|c|c|c|c|}
\hline & AN & SI & $\mathrm{CH}$ & $\mathrm{LI}$ & BL & PI & Average & SEM \\
\hline \multicolumn{9}{|c|}{ Initial live weight (kg) } \\
\hline Series 1 & $290^{\mathrm{ab}}$ & $294^{\mathrm{nb}}$ & $295^{\mathrm{ab}}$ & $288^{\mathrm{ab}}$ & $278^{b}$ & $321^{\circ}$ & $294^{2}$ & 8.9 \\
\hline Series 2 & $342^{b}$ & $343^{b}$ & $391^{\circ}$ & $323^{b}$ & $323^{b}$ & $268^{\mathrm{c}}$ & $332^{y}$ & 9.3 \\
\hline \multicolumn{9}{|c|}{ Final live weight $(\mathrm{kg})$} \\
\hline Series 1 & $478^{b}$ & $631^{\prime \prime}$ & $642^{n}$ & $637^{\prime \prime}$ & $695^{8}$ & $656^{n}$ & $623^{x}$ & 23.1 \\
\hline Series 2 & $524^{\mathrm{d}}$ & $625^{\mathrm{C}}$ & $744^{\circ b}$ & $698^{b c}$ & $820^{\prime \prime}$ & $637^{\mathrm{c}}$ & $675^{y}$ & 18.5 \\
\hline \multicolumn{9}{|c|}{ Age at slaughter (d) } \\
\hline Series I & $368^{\mathrm{d}}$ & $540^{\mathrm{c}}$ & $517^{\mathrm{c}}$ & $605^{b c}$ & $696^{\text {ob }}$ & $705^{n}$ & 572 & 22.5 \\
\hline Series 2 & $393^{c}$ & $477^{d}$ & $540^{c}$ & $614^{b}$ & $683^{n}$ & $660^{\mathrm{sb}}$ & 561 & 12.3 \\
\hline \multicolumn{9}{|c|}{ Days of fattening } \\
\hline Series I & $146^{d}$ & $319^{c}$ & $304^{c}$ & $371^{\mathrm{bc}}$ & $479^{\mathrm{n}}$ & $424^{\mathrm{ab}}$ & $340^{y}$ & 22.1 \\
\hline Series 2 & $140^{\mathrm{C}}$ & $226^{\mathrm{d}}$ & $283^{c}$ & $352^{b}$ & $442^{*}$ & $421^{*}$ & $311^{z}$ & 11.1 \\
\hline \multicolumn{9}{|l|}{ Daily gain $(g / d)$} \\
\hline Series I & $1279^{\prime \prime}$ & $1088^{\text {be }}$ & $1170^{\mathrm{ab}}$ & $951^{\text {ed }}$ & $869^{d}$ & $796^{\mathrm{d}}$ & $1025^{2}$ & 39.7 \\
\hline Series 2 & $1306^{\mathrm{C}}$ & $1252^{\circ b}$ & $1274^{4}$ & $1069^{c}$ & $1123^{\mathrm{bc}}$ & $876^{\mathrm{d}}$ & $1150^{y}$ & 33.0 \\
\hline \multicolumn{9}{|c|}{ DM intake $(\mathrm{kg} / \mathrm{d})$} \\
\hline Series 1 & $7.79^{\text {stic }}$ & $8.21^{\text {th }}$ & $8.26^{n}$ & $7.31^{\mathrm{c}}$ & $7.15^{\circ}$ & $7.51^{\mathrm{bc}}$ & $7.70^{2}$ & 0.178 \\
\hline Series 2 & $8.04^{b}$ & $8.11^{\mathrm{ob}}$ & $8.96^{\circ}$ & $7.79^{6}$ & $8.44^{\mathrm{zb}}$ & $6.79^{c}$ & $8.02^{y}$ & 0.213 \\
\hline \multicolumn{9}{|c|}{ Total energy intake (GJ NEV) } \\
\hline Series I & $7.87^{\circ}$ & $17.89^{\mathrm{b}}$ & $17.20^{\mathrm{b}}$ & $18.64^{a b}$ & $23.50^{\mathrm{a}}$ & $21.93^{\mathrm{ab}}$ & $17.84^{y}$ & 1.240 \\
\hline Series 2 & $7.41^{d}$ & $12.34^{\mathrm{c}}$ & $17.03^{6}$ & $18.51^{\mathrm{b}}$ & $23.82^{\prime \prime}$ & $19.01^{b}$ & $16.36^{x}$ & 0.872 \\
\hline \multicolumn{9}{|c|}{ Total protein intake (kg APD) } \\
\hline Series 1 & $101^{\circ}$ & $226^{\mathrm{b}}$ & $218^{b}$ & $236^{\mathrm{ab}}$ & $296^{\circ}$ & $275^{\text {sb }}$ & 225 & 15.5 \\
\hline Series 2 & $96^{d}$ & $158^{\circ}$ & $217^{b}$ & $236^{\mathrm{b}}$ & $312^{4}$ & $248^{b}$ & 211 & 11.1 \\
\hline \multicolumn{9}{|c|}{ Feed conversion efficiency } \\
\hline \multicolumn{9}{|c|}{ Feed DM/gain $(\mathrm{kg} / \mathrm{kg})$} \\
\hline Series 1 & $6.14^{\mathrm{d}}$ & $7.66^{\mathrm{bc}}$ & $7.11^{\mathrm{cd}}$ & $7.72^{\text {be }}$ & $8.30^{\mathrm{b}}$ & $9.63^{\mathrm{A}}$ & $7.76^{y}$ & 0.265 \\
\hline Series 2 & $6.16^{\circ}$ & $6.51^{\mathrm{bc}}$ & $7.11^{\text {tb }}$ & $7.32^{\circ}$ & $7.47^{a}$ & $7.79^{n}$ & $7.06^{x}$ & 0.193 \\
\hline \multicolumn{9}{|c|}{$\mathrm{NEV} /$ gain $(\mathrm{MJ} / \mathrm{kg}$ ) } \\
\hline Series 1 & $42.6^{\mathrm{d}}$ & $52.6^{\mathrm{bc}}$ & $49.0^{\mathrm{cd}}$ & $53.0^{\text {tce }}$ & $57.1^{\mathrm{b}}$ & $66.2^{\mathrm{a}}$ & $53.4^{y}$ & 1.82 \\
\hline Series 2 & $40,7^{\circ}$ & $43.7^{60}$ & $47.8^{\text {ab }}$ & $49.7^{*}$ & $49.3^{\mathrm{a}}$ & $51.9^{*}$ & $47.2^{2}$ & 1.29 \\
\hline \multicolumn{9}{|c|}{ APD/gain $(\mathrm{g} / \mathrm{kg})$} \\
\hline Series I & $545^{\mathrm{d}}$ & $666^{b c}$ & $621^{\mathrm{cd}}$ & $671^{\mathrm{be}}$ & $720^{b}$ & $830^{a}$ & $675^{y}$ & 22.8 \\
\hline Series 2 & $529^{c}$ & $560^{\mathrm{bc}}$ & $611^{\text {th }}$ & $634^{x}$ & $646^{a}$ & $677^{\circ}$ & $610^{2}$ & 16.3 \\
\hline
\end{tabular}

$\mathrm{AN}=$ Angus, $\mathrm{SI}=$ Simmental, $\mathrm{CH}=$ Charolais, $\mathrm{LI}=$ Limolisin, $\mathrm{BL}=$ Blonde d'Aquitaine, $\mathrm{PI}=$ Piedmontese

'Means within one line without a common superscript differ significantly $(P<0.05)$; series averages within the same variable with different superscripts are significantly different $(P<0.05)$ 
groups had a similar final live weight in series 1 . However, in series $2, \mathrm{CH}$ were the heaviest group of those large-framed breeds which reached the target IMF content. Compared with the weight at slaughter, group differences in age were more pronounced and consequently the duration of fattening greatly differed. BL and PI did not reach the target IMF content on average despite fattening period was three times longer than for AN. BL and PI therefore were on average significantly older at slaughter than all other breeds, and BL were also heaviest while PI remained in the same weight range as SI, LI and $\mathrm{CH}$ (CH series 1 only).



Fig. I: Evolution of the live weight of steers of different beef breeds (average of series I and 2). Curves end when the first animal of the respective breed was slaughtered. The last symbol, connected with the solid line by a dotted line, indicates the average live-weight at slaughter of all animals per group (Zunahme der Lebendmasse von Ochsen verschiedener Mastrassen (Mittelwert von Durchgang 1 und 2). Dic Kurven enden, wenn das erste Tier der jeweiligen Rasse geschlachtet wurde. Das jeweils letzte, mit einer gestrichelten Linie verbundene Symbol gibi die mittlere Lebendmasse aller Tiere derselben Rasse bei Mastende wieder.)

As Figure 1 illustrates, the average live weight gain was quite linear at least in the first 5 to 6 months of fattening, but slightly lower from then on, particularly when regarding the average final weight and fattening duration. The average daily gains were highest in $\mathrm{AN}$, followed by $\mathrm{CH}, \mathrm{SI}$, and LI. BL had average daily gains similar to LI while PI steers showed the lowest growth rates from the beginning on. Overall, an inverse relationship between age at slaughter respectively days of fattening and the average daily gains was observed. The assumed level of daily gains of about $1.2 \mathrm{~kg} / \mathrm{d}$ was reached on average only by $\mathrm{AN}$ and $\mathrm{CH}$ in both series and $\mathrm{SI}$ in series 2 but not by $\mathrm{LI}, \mathrm{BL}$ and PI,

The average daily feed intake over the whole fattening period was, in part, significantly lowest for LI compared with $\mathrm{CH}$, SI and AN (Table 2). The evolution of feed intake during fattening (Figure 2) showed a similar pattern for $\mathrm{AN}, \mathrm{CH}$ and $\mathrm{SI}$ in one group and LI together with $\mathrm{BL}$ in another one while PI where lowest over the 
whole period. The highest feed intake was generally recorded approximately in the middle of the fattening period, shortly before the first individuals of the breed groups reached the target IMF and were assigned to slaughter. The periodically occurring changes in feed intake (Figure 2) could be mainly led back to changes in batches of grass silage. Feed conversion efficiency in terms of DM expenditure per kg gain over the complete fattening period was highest for AN while this efficiency was lowest for LI, significant against efficiency of SI in series 2 and AN when only comparing those breeds which reached the target IMF. PI and BL performed even worse in this respect (Table 2). As diet composition was not changed during fattening, intake and utilization of net energy and absorbable protein showed the same relative group difference as DM intake. According to the days on feed required, the total energy and protein intake was by far lowest for AN and highest for BL and PI.

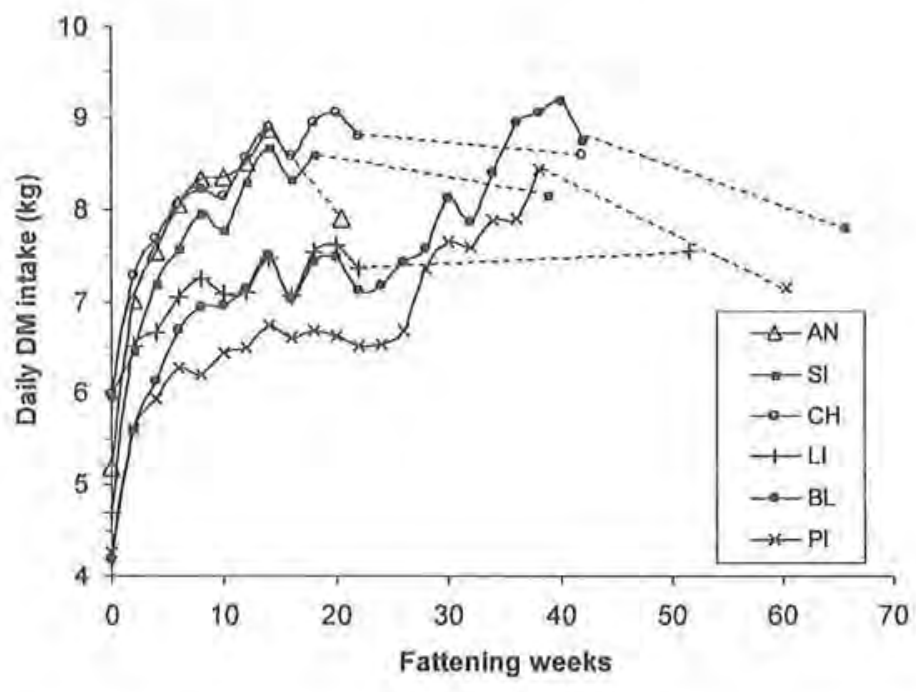

Fig. 2: Evolution of daily dry matter intake of the steers of different beef breeds (average of series I and 2). For explanations see Fig. I. (Verlauf der täglichen Trockenmasseaufnahme von Ochsen verschiedener Mastrassen (Mittelwerl von Durchgang 1 und 2). Erklărungen siehe Abb, I.)

In series 2, the steers started and finished fattening with a higher weight and had daily gains higher by $125 \mathrm{~g} / \mathrm{d}$ on average compared with those found in series 1 . The age at slaughter, however, was similar (Table 2). Differences between the two series in live weight at slaughter were particularly high for $\mathrm{BL}, \mathrm{CH}, \mathrm{LI}$ and $\mathrm{AN}$ with $+18,+16,+11$ and $+10 \%$ in series 2, respectively, but low in SI and PI. In line with the higher daily gains, feed consumption was significantly elevated in series 2 , but also feed conversion efficiency was improved relative to series I, particularly in PI ( $-19 \%$ feed $\mathrm{DM} / \mathrm{kg}$ gain), SI $(-15 \%)$ and BL $(-10 \%)$. Overall, the steers required $7.4(6.1-9.6)$ $\mathrm{kg}$ DM, 50 (41-66) MJ NEV and 643 (529-830) g APD per $\mathrm{kg}$ of weight gain. 


\subsection{Carcass quality}

Dressing percentage was significantly different between breed groups being particularly high in LI and also in BL and PI (Table 3). $\mathrm{CH}$ were intermediate and AN as well as SI were lower in dressing percentage by approximately 8 units in relation to LI. This increased the relative group differences from live weight to slaughter weight, particularly in series 1. Carcass length increased with increasing slaughter weight but not generally at the same proportion in all groups. LI and PI were similar in carcass length as SI despite clearly higher slaughter weights which is reflected in a better conformation of LI and PI carcasses.

Table 3

Carcass quality traits of the steers originating from different beef breeds (Schlachtkörperqualităt der Ochsen von verschiedenen Mastrassen)!

\begin{tabular}{|c|c|c|c|c|c|c|c|c|}
\hline & AN & SI & $\mathrm{CH}$ & $\mathrm{LI}$ & BL & PI & Average & SEM \\
\hline \multicolumn{9}{|c|}{ Hot carcass weight $(\mathrm{kg})$} \\
\hline Series I & $261^{d}$ & $347^{c}$ & $375^{\mathrm{be}}$ & $398^{\mathrm{abc}}$ & $447^{\mathrm{a}}$ & $413^{\text {ab }}$ & $374^{2}$ & 15.3 \\
\hline Series 2 & $282^{d}$ & $333^{\mathrm{c}}$ & $426^{\mathrm{b}}$ & $424^{\mathrm{b}}$ & $514^{*}$ & $401^{\mathrm{b}}$ & $397^{y}$ & 10.7 \\
\hline \multicolumn{9}{|c|}{ Dressing percentage $(\%)$} \\
\hline Series 1 & $54.5^{\mathrm{c}}$ & $55.0^{\mathrm{e}}$ & $58.0^{\mathrm{b}}$ & $62.5^{a}$ & $64.3^{a}$ & $63.1^{\mathrm{a}}$ & $59.6^{y}$ & 0.59 \\
\hline Series 2 & $53.9^{d}$ & $53.4^{\mathrm{d}}$ & $57.4^{\mathrm{c}}$ & $60.8^{b}$ & $62.8^{a}$ & $62.9^{n}$ & $58.5^{2}$ & 0.39 \\
\hline \multicolumn{9}{|c|}{ Carcass length $(\mathrm{cm})$} \\
\hline Series 1 & $129^{\mathrm{c}}$ & $136^{\text {ab }}$ & $134^{\mathrm{nbc}}$ & $134^{\mathrm{be}}$ & $140^{n}$ & $137^{\mathrm{tb}}$ & 135 & 1.6 \\
\hline Series 2 & $130^{\mathrm{c}}$ & $135^{b c}$ & $140^{\mathrm{nb}}$ & $136^{6 c}$ & $145^{a}$ & $135^{\mathrm{bc}}$ & 137 & I.5 \\
\hline \multicolumn{9}{|c|}{ Carcass grading } \\
\hline \multicolumn{9}{|c|}{ Conformation score ${ }^{2}$} \\
\hline Series 1 & $2.6^{\mathrm{a}}$ & $2.3^{3}$ & $1.2^{\mathrm{b}}$ & $1.1^{b}$ & $1.2^{b}$ & $1.4^{b}$ & 1.6 & 0.14 \\
\hline Series 2 & $2.5^{2}$ & $2.4^{2}$ & $1.0^{\mathrm{b}}$ & $1.0^{6}$ & $1.0^{6}$ & $1.4^{\mathrm{b}}$ & 1.5 & 0.09 \\
\hline \multicolumn{9}{|c|}{ Fatness score ${ }^{3}$} \\
\hline Series I & $4.4^{\prime \prime}$ & $4.0^{3 b}$ & $3.7^{6}$ & $3.9^{\mathrm{ab}}$ & $3.0^{\circ}$ & $3.1^{\circ}$ & $3.7^{2}$ & 0.14 \\
\hline Series 2 & $4.8^{2}$ & $4.2^{6 b}$ & $4.4^{n b}$ & $4.5^{\mathrm{nb}}$ & $3.7^{b}$ & $2.9^{c}$ & $4.1^{y}$ & 0.19 \\
\hline \multicolumn{9}{|c|}{ Subcutaneous fat layer (mm) } \\
\hline Series I & $11,8^{n}$ & $12.6^{a}$ & $11.0^{\mathrm{ab}}$ & $11.9^{n}$ & $7.0^{\mathrm{bc}}$ & $5.7^{c}$ & 10.0 & 1.09 \\
\hline Series 2 & $16.2^{\mathrm{n}}$ & $12.5^{\mathrm{Ab}}$ & $13.1^{\mathrm{ab}}$ & $12.2^{b}$ & $7.3^{\circ}$ & $3.4^{\mathrm{d}}$ & 10.8 & 0.90 \\
\hline
\end{tabular}

Means within one line without a common superscript differ significantly $(\mathrm{P}<0.05)$; series averages within the same variable with different superseripts are significantly different $(\mathrm{P}<0.05)$

'Conformation score: $\mathrm{C}=1, \mathrm{H}=2, \mathrm{~T}=3, \mathrm{~A}=4, \mathrm{X}=5$ (widely cquivalent to EUROP grading with $\mathrm{C}=\mathrm{E}$ )

'Fatness score: 1 (low) to 5 (high fatness) equivalent to EUROP grading

Carcass grading led to a differentiation into two distinct groups of breeds. LI, CH, BL and PI were generally present in the best conformation class while AN and SI were graded significantly lower. In contrast, fatness score and thickness of the subcutaneous fat layer only slightly differed among the four breeds reaching the target IMF content although AN showed a trend to the highest fatness. Generally these breeds were graded above 4 . BL and PI, which did not reach the target IMF, provided significantly leaner carcasses with a far lower subcutaneous fat thickness, particularly for PI. The within breed correlations between thickness of the subcutaneous fat layer and IMF content were significant in BL and $\mathrm{CH}$ with 0.50 and $0.46(\mathrm{p}<0.05)$, respectively, but not significant in LI (0.27), PI (0.18) and SI $(0.03)$ and even negative in AN $(-0.30)$ due to two AN steers with simultaneously high IMF content and few subcutaneous fat. AN carcasses showed the lowest pistola proportion (significant against $\mathrm{CH}$ and LI in the first and against BL and PI in both series) but the differences between breed groups 
were low compared with those found in other carcass variables (Table 4). However, AN were also lowest in percentage of $1^{\text {st }}$ category cuts, significantly so against $\mathrm{LI}$ and partly also $\mathrm{CH}$. BL and PI carcasses were high in percentage of $1^{\text {st }}$ category cuts, striploin proportion of sirloin, lean to bone ratio and particularly lean to fat ratio. In descending order, these variables were less favourable in $\mathrm{LI}, \mathrm{CH}, \mathrm{SI}$ and $\mathrm{AN}$. Tenderloin proportion of sirloin was highest in BL while PI, LI, CH and SI expressed intermediate levels and AN carcasses were lowest in this respect. Most of these group differences were observed in both series although the level of differences varied to a certain extent. Average values calculated over all groups were also similar in both series, except the slightly but significantly lower proportion of $1^{\text {st }}$ category cuts in series 2 relative to series 1 .

Table 4

Properties of the valuable cuts in the carcass of the steers originating from different beef breeds (Eigenschaften der wertvollen Teilstúcke im Schlachtkörper der Ochsen von verschiedenen Mastrassen)'

\begin{tabular}{|c|c|c|c|c|c|c|c|c|}
\hline & $\mathrm{AN}$ & SI & $\mathrm{CH}$ & $\mathrm{LI}$ & BL & PI & Average & SEM \\
\hline \multicolumn{9}{|c|}{ Pistola (\% of carcass weight) } \\
\hline Series 1 & $41.3^{5}$ & $41.6^{\mathrm{bc}}$ & $43.5^{4}$ & $42.9^{\mathrm{ab}}$ & $43.2^{4}$ & $43.3^{2}$ & 42.6 & 0.34 \\
\hline Series 2 & $41.3^{\mathrm{b}}$ & $42.0^{\mathrm{ab}}$ & $42.0^{a b}$ & $42.1^{t b}$ & $42.9^{\mathrm{a}}$ & $43.3^{\circ}$ & 42.3 & 0.34 \\
\hline \multicolumn{9}{|c|}{ I" category cuts ${ }^{2}$} \\
\hline \multicolumn{9}{|c|}{ ( $\%$ of carcass weight) } \\
\hline Series 1 & $6.8^{\mathrm{e}}$ & $7.1^{b e}$ & $7.3^{\mathrm{b}}$ & $7.9^{a}$ & $8.2^{\circ}$ & $8.2^{2}$ & $7.6^{\gamma}$ & 0.11 \\
\hline Series 2 & $6.6^{c}$ & $7.0^{\mathrm{bc}}$ & $7.0^{\mathrm{bc}}$ & $7.4^{6}$ & $8.0^{\circ}$ & $8.1^{\circ}$ & $7,4^{2}$ & 0.10 \\
\hline \multicolumn{9}{|c|}{ Sirloin composition } \\
\hline \multicolumn{9}{|c|}{ Striploin ${ }^{3}$ (\% of sirloin) } \\
\hline Series 1 & $36.6^{\mathrm{b}}$ & $35.7^{b}$ & $36.6^{b}$ & $40.4^{n}$ & $39.6^{x}$ & $39.4^{n}$ & 38.1 & 0.60 \\
\hline Series 2 & $34.2^{b}$ & $35.3^{b}$ & $35.9^{\mathrm{b}}$ & $38.6^{\circ}$ & $40.5^{x}$ & $40.5^{A}$ & 37.5 & 0.50 \\
\hline \multicolumn{9}{|c|}{ Tenderloin ${ }^{4}(\%$ of sirloin) } \\
\hline Series 1 & $12.6^{c}$ & $15.6^{\mathrm{b}}$ & $15.5^{b}$ & $16.0^{b}$ & $18.5^{\mathrm{s}}$ & $16.5^{\mathrm{b}}$ & 15.8 & 0.40 \\
\hline Series 2 & $12.8^{\mathrm{c}}$ & $14.4^{\mathrm{b}}$ & $15.1^{\mathrm{b}}$ & $14.6^{6}$ & $17.3^{\mathrm{a}}$ & $18,5^{\circ}$ & 15,5 & 0,35 \\
\hline \multicolumn{9}{|c|}{ Lean / fat ratio } \\
\hline Series 1 & $4.3^{\mathrm{c}}$ & $5.2^{\mathrm{bc}}$ & $5.7^{b c}$ & $7,0^{6}$ & $12.0^{\mathrm{a}}$ & $10.6^{3}$ & 7.5 & 0.62 \\
\hline Series 2 & $3.5^{\mathrm{d}}$ & $5,4^{\mathrm{c}}$ & $5.2^{\text {ed }}$ & $5.5^{\mathrm{c}}$ & $9.0^{\mathrm{b}}$ & $13.9^{8}$ & 7.1 & 0.43 \\
\hline \multicolumn{9}{|c|}{ Lean / bone ratio } \\
\hline Series 1 & $3.9^{6}$ & $3.9^{b}$ & $4.0^{b}$ & $5.3^{\prime \prime}$ & $5.0^{\prime \prime}$ & $4.9^{2}$ & 4.5 & 0.13 \\
\hline Series 2 & $3.8^{\mathrm{d}}$ & $3.9^{d}$ & $4.2^{\mathrm{ed}}$ & $4.7^{\text {bc }}$ & $5.6^{*}$ & $5.1^{\text {sh }}$ & 4.5 & 0.13 \\
\hline
\end{tabular}

4. Discussion

This study compared steers of different breeds deliberately not slaughtered at the same age or weight but at a target IMF. This implies that differences in growth rates and carcass size-related properties between steers of different breed are not reflecting those usually found. The targeted IMF level was reached on average only in the $\mathrm{AN}, \mathrm{CH}, \mathrm{LI}$ and SI steers, whereas in BL and PI not a single individual animal was able to reach this level although the fattening period was largely extended. For this reason, the present results include both a comparison among those breeds which were potentially able to meet the target level and a comparative description of properties found in two 
breeds which were unable to meet this target but were fattened up to the maximum IMF content possible under the feeding and housing conditions described.

\section{1 \\ Growth development of steers of different breeds fattened to a similar IMF content}

Steers were already 8 months of age when entering the fattening period because they had been reared under the relatively extensive conditions of suckler systems. Differences in genetic growth potential and, possibly, rearing environment led to certain initial weight differences between breed groups. Using a medium-energy density ration (6.9 MJ NEV $/ \mathrm{kg}$ DM, equivalent to $11.2 \mathrm{MJ} \mathrm{ME} / \mathrm{kg}$ ) from then on was found to yield the typical, widely linear growth development in all breeds with daily gains gradually declining not before several months of fattening had passed, whereas very intensive feeding gives a clear peak in growth rate as shown earlier in bulls (GERHARDY et al., 1995). Although the ration was calculated to provide sufficient energy and protein for average daily gains of $1.2 \mathrm{~kg}$ (RAP, 1999), this level was only reached by the groups fattened for comparably short periods of time (AN, SI and $\mathrm{CH}$, particularly in series 2). It has to be kept in mind that this assumed level was derived from data on dairy crossbred steers fattened up to $550 \mathrm{~kg}$. A prolonged period of fattening is very likely to decrease overall daily gains and, particularly, feed conversion efficiency due to the increasing proportion of nutrients and energy required to cover demands for maintenance relative to growth and fat retention (CROUSE et al., 1985).

Accordingly, very low average daily gains and a particularly poor feed conversion efficiency were found in PI compared with all other breeds. The lower feed conversion efficiency observed in PI of series 1 is partially due to the age difference at the start of the trial as animals were older by $41 \mathrm{~d}$ in series 1 . The BL being slaughtered approximately at the same age nevertheless performed significantly better than PI although also ranked behind the other breeds in most fattening performance traits particularly in series 1 . This additional difference to BL could have been at least partly due to the low feed intake capacity of the PI steers which was obvious throughout the whole fattening period (Figure 2). These findings are in agreement with the study of TARTARI et al. (1988), who compared PI, CH and LI bulls reared for 251 days under identical conditions kept individually in a tied stall. Accordingly, PI bulls had the lowest stomach and gut proportions of empty body weight. This anatomical disadvantage of PI is enlarged by feeding diets of low energy density (GEAY and MICOL, 1988; TARTARI et al., 1988). Another component particularly affecting the performance of PI and BL steers were the housing conditions in series 1 , which were unsuitable for the long duration of fattening and the very high live weights reached. Accordingly, in series 1 eight out of eleven BL steers and five out of eleven PI steers expressed joint and leg problems during the last fattening weeks, due to restrictions in movement in the tie-stall barn. This explains the particularly high difference between series in average daily gains of BL steers whereas series differences were lower in all other groups, especially in AN with the shortest fattening period. Furthermore, this illustrates that an unfavourable housing system may affect the expression of breed differences in performance of steers of suckler origin. Other factors such as diet and 
season within year did not differ between series and so presumably were without major effect in the present study. The importance of individual vs group housing of cattle for the result of a breed comparison has also been reported earlier (COLE et al., 1964; MIR et al., 1999).

Among the breeds reaching the target IMF content, LI required the most extended fattening period and had lower growth rates than SI and particularly AN and $\mathrm{CH}$ steers. LI are known for their high feed conversion efficiency compared to other breeds at the same slaughter age (GEAY, 1982; GEAY and MICOL, 1988), but this was obviously more than compensated by the adverse effect of prolonged fattening in the present study. This is confirmed by the longest fattening period and the lowest feed conversion efficiency found by SMITH et al. (1976) in LI crosses when comparing carcasses of purebred AN to AN crosses with SI, CH and LI at the same IMF content of $5 \%$. LI have a lower digestive tract weight percentage of empty body weight than $\mathrm{CH}$ though still far higher than PI (TARTARI et al., 1988). Compared to $\mathrm{CH}$, voluntary intake of bulky diets in LI therefore seems to be more restricted by the volume of the abdominal cavity, especially that of the rumen, than by energy requirements (GEAY and MICOL, 1988) also suggesting the use of diet of a higher energy content for LI. In line with this, GEAY and ROBELIN (1979) demonstrated that, for a given body weight, a certain combination of energy intake and growth rate is ideal in terms of feed conversion efficiency. Typically, in an advanced growth stage late-maturing cattle show higher weight gains at the same age than early-maturing animals, provided feed quantity and quality are not limiting factors (LEHMANN, 1979; JENKINS and FERREL, 1984; SHORTHOSE and HARRIS, 1991) as possibly was the case in our study.

\section{2 \\ Carcass characteristics of steers of different breeds fattened to a similar} IMF content

Large-framed late-maturing cattle are typically physiologically younger at the same chronological age than small-framed early-maturing cattle and have a higher priority for protein accretion, especially at limited growth rates (BYERS et al., 1988) as was the case in our study in contrast to typical feedlot conditions (MICOL et al., 1993). These prerequisites made extended fattening periods inevitable to reach or try to approach the target level in IMF. As a consequence carcasses were much heavier than in the early-maturing $\mathrm{AN}$ steers. This provided best graded carcasses in conformation scores and high dressing percentages in the late-maturing breeds. ROBELIN (1986) and SZÜCS et al. (2001) showed that the dressing percentage increases with age and/or weight. Thus, the great differences in slaughter ages between groups enlarged the differences in dressing percentage. The ratio of leg length to carcass weight is an indicator of compactness (KEANE and ALLEN, 1998) and well reflected the better conformation of the later maturing cattle, i.e. BL, PI and LI (data not shown). Among the four breeds reaching the target IMF content, LI steers showed the best carcass value in terms of the lean tissue-related properties. The superiority of LI compared to $\mathrm{CH}$, SI and $\mathrm{AN}$ is in agreement with other studies comparing LI and SI (BYERS et al., 1988), LI and CH (GEAY and MALTERRE, 1973; GEAY, 1982) as well as LI, SI and 
AN (GEAY and MALTERRE, 1973; GEAY, 1982; GEAY and MICOL, 1988). Also dressing percentage of LI steers was clearly higher than that of AN, SI and $\mathrm{CH}$, an effect which was even obvious in crossbred bulls slaughtered at similar age or weight when comparing LI and SI (with Red Holstein blood) sired bulls (GERHARDY, 1994),

However, one unfavourable consequence of slaughter according to a high target IMF was that the $1^{\text {st }}$ category cuts were too big in size for the common retail market, particularly with the large-framed breeds. Furthermore, the carcasses were excessively fat. It is well-known that deposition of fat in the body cavity, between the muscles, and in the subcutaneous site occurs earlier than the deposition of fat within muscle to be noted as marbling (SMITH, 1988). This explains why carcasses in terms of European continental demand were extraordinarily fat even before a sufficiently high IMF content was reached, ROBELIN (1978) found no significant differences in IMF content among Holstein, Salers, Charolais and Limousins bulls, i.e. four breeds differing in maturity, when their fatness scores were identical, which supports the assumption that fat deposition in different body sites is related. However, in our study, correlations between the thickness of the subcutaneous fat layer and the intramuscular fat were rather low, if significant at all, or even negative (AN). This can be explained by the deliberately reduced variation in IMF content by applying a target value but possibly also from the difference in fat retention during growth phases between adipose tissues and within muscle. It should be noted that the genetic correlation reported by the American Angus Association between marbling score and external backfat thickness at the $12^{\text {th }}$ rib is nearly zero (AAA, 2001). Similar to the results in the other breeds, CAMPION and CROUSE (1975) found correlations between the same variables in the range of 0.41 to 0.46 depending on sire and dam breed, whereas the genetic correlation reported by GEAY and RENAND (1994) was even higher with 0.64 . Regarding the very similar fatness of the large framed breeds which reached the same IMF content under identical feeding conditions in our study, it may be assumed that the ratios of undesired subcutaneous fat and intermuscular fat to IMF is more variable within than between similarly maturing breeds. The AN, by contrast, already developed significantly more depot fat in relation to IMF and were not able to develop a highly favourable conformation or muscling within the period required to reach 3.5 $\%$ IMF. In the later maturing breeds, however, the target IMF content together with a good conformation was only achieved at a rather late growth stage resulting in very heavy carcasses. Overall, the very good conformation scores can be assumed to be not sufficient to economically compensate the unfavourably big-sized cuts and the excessive fatness.

\subsection{Dietary energy concentration required for steers of different breeds fattened to a similar IMF content}

A limitation in dietary energy density could have been beneficial in the case of the early-maturing AN steers in terms of feed conversion efficiency while the contrary is true for the two late-maturing breeds, PI and BL, but also for LI. When using purebred AN instead of $75 \%$ AN steers, as in the present study, a limitation in dietary energy concentration and/or restricted feeding would have been even more advisable. Also 
from the carcass quality aspect the present study provides indirect evidence regarding the search for the ideal energy density of the diet. Although energy content of the diet was high enough to reach $3.5 \%$ IMF at least in four breeds, the fattening period presumably could have been reduced by a more concentrated ration. This would be particularly advantageous for those breeds whose feed intake may be a limiting factor, i.e. LI and also BL and of course PI, but is highly recommendable in all breeds, except $\mathrm{AN}$, in order to obtain smaller-sized valuable cuts, In contrast, for the AN a slightly extended fattening period would also be tolerable from the viewpoint of slaughter weight which would increase due to the longer time span required to reach $3.5 \% \mathrm{IMF}$. The final extent of fat deposition in AN steers, however, would probably not be reduced under these conditions. From the present results it remains open whether or not the genetic limitations in BL and PI would still have prevented to reach the level of $3.5 \%$ IMF when offering a ration of higher energy density.

\section{Conclusions}

Out of the six breeds investigated only AN, SI, CH and LI, turned out to be able to reach the target IMF content of $3.5 \%$ in a fattening system based on a forage-based diet of medium-level energy concentration following an 8 months rearing period as suckler beef. BL and PI did not retain the desired amount of IMF, obviously due to the limited feed intake and the genetic predisposition for a very high protein accretion. All breeds except AN, however, had to be fattened for unusually long periods and provided carcasses too heavy to be acceptable for the common beef market as well as for existing label programs. Although the carcasses of the AN were of common size, the ratio of carcass fatness to IMF was the most undesirable of all breeds compared. Generally, the carcasses of all those breeds which reached the desired IMF content were unacceptably fat. Thus, the present results revealed the difficulty to find an acceptable compromise between a desired extent of marbling as well as favourable carcass conformation on one hand and carcass size as well as fat cover which meet market demands on the other hand.

\section{Acknowledgements}

This study was financially supported by SVAMH (Schweizerische Vereinigung der Ammen- und Mutterkuhhalter), Brugg, Switzerland and Proviande, Berne, Switzerland.

\section{References}

AAA (American Angus Association): Angus Sire Evaluation Results - Spring 2001, American Angus Association home page. Available al: http://www.angus.org/sireeval/carcass.html (2001). Accessed Apr. 5, 2001

ABZ (Ausbildungszentrum fur die Schweizer Fleischwirtschaft): Die Benennung der Fleischstucke und ihre Verwendung. Spiez, Switzerland (1997), 2-20

AUGUSTINI, C;; TEMISAN, V; KALM, E; GUHE, M.; Mastintensităt und Fleischqualitát beim Rind. Fleischwirtsch. 108 (1990), 123-129

BADERTSCHER FAWAZ, R.; JÖRIN, R.; RIEDER, P.: Nachfrage nach Fleisch aus besonders tierfreundlicher Haltung. Agrarforsch. 5 (1998), 57-60 
BUTTERY, P. J.; BRAMELD, J, M.; DAWSON, J. M.; SENSKY, P. L; PARR, T.; SALTER, A. M;

BARDSLEY, R. G.; RICHARDS, S. E.; HARPER, J. M. M.; GREATHEAD, H. M. R.: Production systems and quality. In: Vitality of Meat. Proc. $43^{\text {rd }}$ ICOMST. J, Bass (Editor), Auckland, New Zealand (1997), 20-21

BYERS, F. M.; CROSS, H. R.; SCHELLING, G. T:

Integrated nutrition, genetics, and growth management programs for lean beef production. In: Designing Foods, Animal Product Options in the Marketplace. National Research Council (Editor), National Academy Press, Washington D.C., USA (1988), 283-291

CAMPION, D. R; CROUSE, J. D.:

Predictive value of USDA beef quality grade factors for cooked meat palatability. J. Food Sci. 40 (1975), 1225-1228

CHAMBAZ, A.; KREUZER, M.; SCHEEDER, M. R. L,; DUFEY, P.-A.;

Characteristics of steers of six beef breeds fattened from eight months of age and slaughtered at a target level of intramuscular fat. II. Meat quality. Arch. Anim. Breed. submitted (200I)

COLE, J. W.; RAMSEY, C. B.; HOBBS, C. S.;

Effects of type and breed of British, zebu, and dairy cattle on production, carcass composition, and palatability. J. Anim. Sci. 47 (1964), 1138-1144

CROUSE, J. D,; FERREL, C. L.; CUNDIFF, L. V.: Effects of sex condition, genotype and diet on bovine growth and carcass characteristics. J. Anim. Sci. 60 (1985), 1219-1227

DIKEMAN, M. E; CROUSE, J. D.: Chemical composition of carcasses from Hereford, Limousin and Simmental crossbred cattle as related to growth and meat palatability. J. Anim. Sci. 40 (1975), 463-467

DLG (Deutsche Landwirtschaftsgesellschaft):

DLG-Futterwerttabellen Wiederkäuer. $7^{\text {th }}$ ed., Universitat Hohenheim Dokumentationsstelle, DLGVerlag, Frankfurt am Main (1997)

DUBESKI, P. L.; AALHUS, J. L.; JONES, S. D. M.; TONG, A. K. W.; ROBERTSON, W. M.: Fattening heifers to heavy weights to enhance marbling: efficiency of gain. Can. J. Anim. Sci. 77 (1997), 625-633

DUFEY, P.-A; CHAMBAZ, A.:

GEAY, Y:

Labelproduktion in der Schweiz und Rindfleischqualităt. Agrarforsch. 6 (1999), 349-35I

Production de taurillons de 13, 16 et 19 mois. Bull. Techn. CRZV Theix INRA 48 (1982), 21-26

GEAY, Y,; MALTERRE, C.:

Croissance, rendement et composition des carcasses de jeunes bovins de différentes races, Bull. Techn. CRZV Theix INRA I4 (1973), 17-20

GEAY, Y:; MICOL, D.:

Utilisation of large sized cattle breeds in the main fattening systems in continental Europe. In: Proc. $3^{\text {id }}$ World Congress on Sheep and Beef Cattle Breeding. INRA (Editor), Paris (1988), 113-126

GEAY, Y; RENAND, G.:

Importance de la variabilité génétique et du mode d'élevage des bovins sur les caractéristiques musculaires et les qualités organoleptiques de leurs viandes. Renc. Rech. Ruminants 1 (1994), 177-182

GEAY, Y,; ROBELIN, J.:

Variation of meat production capacity in cattie due to genotype and level of feeding: genotype-nutrition interaction. Livest. Prod. Sci. 6 (1979), 263-276

GERHARDY, H.:

Untersuchung einer marktorientierten Fleischerzeugung auf der Basis von Schwarzbunten Jungbullen und Fleckvieh-, Limousin- und Weiss-blaue Belgier-Kreuzungen. Zuchtungskunde 66 (1994), 281-296

GERHARDY, H.; KREUZER, M.; LANGHOLZ, H.-J.: Untersuchungen zur Erzcugung von Qualitätsrindfleisch mit schwarzbunten Jungbullen in Mastverfahren mit unterschiedlicher Mastdauer und -intensitat. Zilchtungskunde 67 (1995), 117-131

GOUTEFONGEA, R.; VALIN, C..

Etude de la qualité des viandes de bovin. Comparaison des caractéristiques organoleptiques des viandes de taurillon et d'animal adulte. Ann. Techn. Agric. 27 (1978), 609-627

GRESHAM, J. D.:

Introduction to characterization of live beef muscle tissue by use of the Pie 200 Scanner quality indexing program: an automated system for estimating quality grade of bcef animals. The Ultrasound Review. Classic Ultrasound Equipment, 19900 Mona Road, Suite 105, Tequesta, FL 33469, (1996) 
HARRINGTON, G:

Consumer demands: major problems facing industry in a consumer-driven society. Meat Sci. 36 (1994), 5-18

JENKINS, T. G.; FERREL, C. L: Characterization of post-weaning traits of Simmental and Hereford bulls and heifers. Anim. Prod. 39 (1984), 355-364

KAUFMANN, G.; CHAVAZ, J.? Vergleich der Fleischleistung von Blonde d'Aquitaine- und Simmentaler M-Gebrauchskreuzungen. 1. Teil: Mast- und Schlachtleistung, Landwirtsch. Schweiz 2 (1989), 469-476

KEANE, M.G.; ALLEN, P.: Effects of production system intensity on performance, carcass composition and meat quality of beef cattle. Livest. Prod. Sci. 56 (1998), 203-214

LEHMANN, R:

Theoretische Betrachtungen zur Anwendung der Wachstumsfunktion. Arch. Tierz., Berlin 22 (1979), 381-393

MICOL, D,; ROBELIN, J,; GEAY, Y.:

Composition corporelle et caractéristiques biologiques des muscles chez les bovins en croissance et à l'engrais. INRA Prod. Anim. 6 (1993), 61-69

MIR, P. S.; BAILEY, D. R. C; MIR, Z.; ENTZ, T;; JONES, S. D. M;; ROBERTSON, W. M.; LOZEMAN, F.J.: Growth, carcass and meat quality characteristics of beef cattle with 0,50 and 75 percent Wagyu genetic influence. Can. J. Anim. Sci. 79 (1999), 129-137

OLDIGS, B.; LANGHOLZ, H.-J.; GROENEWOLD, J. P.:

Der Einfluss endogener Faktoren auf die Fleischbeschaffenheit beim Rind. Untersuchungsergebnisse aus einer Mutterkuhherde, 2. Fleischqualitatsfaktoren. Fleischwirtschaft 70 (1989), 108-114

PROVIANDE:

Einschätzungssystem fär grosses Schlachtvieh und Schlachtkąlber. Schweizerische Genossenschaf für Schlachtvieh-und Fleischversorgung (Editor), Bern, Switzerland (200I), I6pp.

RAP (Recherches agronomique Posieux):

Futterungsempfehlungen und Nährwerttabellen für Wiederkäuer. $4^{\text {th }}$ ed., Landwirtschaftliche Lehrmittelzentrale, Zollikofen, Switzerland (1999)

RILEY, R. R.; SMITH, G. C.; CROSS, H. R.; SAVELL, J. W.; LONG, C. R.; CARTWRIGHT, T. C.:

Chronological age and breed-type effects on carcass characteristics and palatability of bull beef: Meat Sci. 17 (1986), 187-198

ROBELIN, J.:

Repartition des dépôts adipeux chez les bovins selon l'état d'engraissement, le sexe et la race, Bull. Techn, CRZV Theix INRA 34 (1978), 31-34

ROBELIN, J,;

Composition corporelle des bovins: évolution au cours du développement et différences entre races. Université de Clermont-Ferrand II. Thèse de doctorat d'état (1986)

SAVELL, J. W.; CROSS, H. R.:

The role of fat in the palatability of beef, pork, and lamb. In: Designing Foods, Animal Product Options in the Marketplace. National Research Council (Editor), National Academy Press, Washington D.C., USA (1988), 345-355

SCHLÄPFER, E.:

Bewertung und Einschätzung von Schlachttieren der Kategorien Kuhe, Jungbullen und Kaiber unter schweizerischen Verhältmissen. ETH Zurich, Switzerland. Diss. No. 8560 (1986)

SHORTHOSE, W. R; HARRIS, P. V.:

Effects of growth and composition on meat quality. In: Growth Regulation in Farm Animals. A. M. PEARSON and T. R. DUTSON (Editors), Elsevier Applied Science, London and New York (1991), 515-555

SMITH, G. C.:

Possible impacts of changes on USDA grade standards and labeling. In: Designing Foods, Animal Product Options in the Marketplace. National Research Council (Editor), National Academy Press, Washington, D.C., USA (1988), 332-344

SMITH, G. M.; LASTER, D. B.; CUNDIFF, L. V; GREGORY, K. E.:

Characterization of biological types of cattle. II. Postweaning growth and feed efficiency of steers. J. Anim. Sci, 43 (1976), 37-47 
SZÜCS, E.; ENDER, B.; PAPSTEIN, H.-J; NÜRNBERG, G.; ENDER, K..

Vergleich des Schlacht- und Nahrwertes sowie der Fleischbeschaffenheit von Jungbullen der Rassen Deutsches Fleckvieh und Deutsche Holsteins (Schwarzbunte) im Verlauf des Wachstums. 1. Mitteilung: Wachstum und Schlachtkörperzusammensetzung. Zltchtungskunde 73 (2001), 33-44

TARTARI, E; DESTEFANIS, G.; BENATTI, G.; ZOCCARATO, I:

La qualita della carne e le sue variazioni in fuzione delle razze di appartenenza dei soggetti allevati: le modalita di allevamento ed i rilievi alla macellacione. In: Le richezze della nostra terra: la carne bovina, Torino, Italy (1988), 79-86

Reccived: 2001-04-01

Accepted: 2001-05-04

Authors' addresses

Dipl.-Ing, agr. ALAIN CHAMBAZ, Dipl.-Ing, agr. ISABELLE MOREL, Dipl.-Ing, agr. PIERRE-ALAIN DUFEY

Swiss Federal Research Station for Animal Production

CH-1725 Posieux

Switzerland

Dr. MARTIN R. L. SCHEEDER, Prof. Dr. MICHAEL KREUZER *

Institute of Animal Sciences, Animal Nutrition

ETH Zurich, ETH-Zentrum

$\mathrm{CH}-8092$ Zurich

Switzerland

*Corresponding author 
TAGUNGSANKÜNDIGUNG

$$
6^{\text {th }} \text { International Symposium }
$$

\section{"Systems of Animal Breeding and Economic of Animal Production at the Beginning of the New Millennium" \\ Belgrade-Zemun, Yugoslavia}

\section{October, 2 - 5, 2001}

Organizer: Institute for Animal Husbandry

Belgrade-Zemun,

P. O. Box 23

11081 Zemun

Yugoslavia

\section{Contact: Dr Branislav Miscevic}

Secretary of the Organizing Committee

tel.

$+38111670185$

$+30111691611$

fax. $\quad+38111670164$

E-Mail: iahbeg@eunet.yu

Registration fee in the amount of 50 USD per person includes Symposium material, Proceedings "Biotechnology in Animal Husbandry", reception cocktail, certificate, entry for all sessions.

(Payment at the registration desk)

\section{Sessions}

1. Systems for rearing domestic animals

2. Systems of fish management

3. Systems for rearing game

4. The economic of animal production

Participating countries: Bulgaria, Brazil, Egypt, France, Germany, India, Italy, Norway, Poland, Pakistan, Romania, Saudi Arabia, Slovakia, USA, Uzbekistan, Yugoslavia 